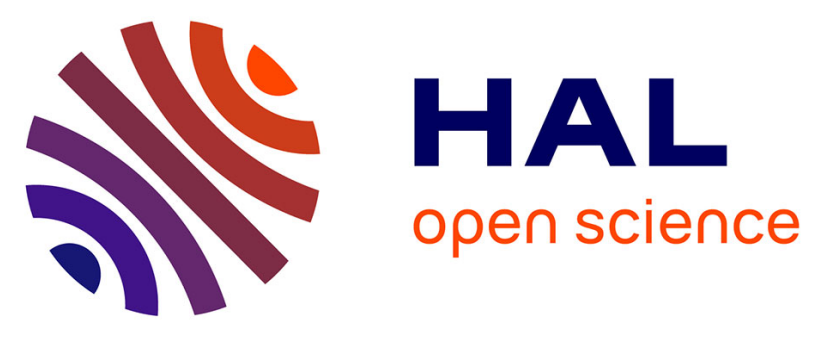

\title{
Specificity of resistance and tolerance to cucumber vein yellowing virus in melon accessions and evidence for resistance breaking associated with a single mutation in $\mathrm{VPg}$
}

Cecile Desbiez, Maria Luisa Domingo Calap, Michel Pitrat, Catherine Wipf-Scheibel, Gregory Girardot, Inmaculada Ferriol, Juan Jose Lopez-Moya, Hervé Lecoq

\section{- To cite this version:}

Cecile Desbiez, Maria Luisa Domingo Calap, Michel Pitrat, Catherine Wipf-Scheibel, Gregory Girardot, et al.. Specificity of resistance and tolerance to cucumber vein yellowing virus in melon accessions and evidence for resistance breaking associated with a single mutation in VPg. Phytopathology, 2022, 112 (5), pp.1185-1191. 10.1094/PHYTO-06-21-0263-R . hal-03428436

\author{
HAL Id: hal-03428436 \\ https://hal.inrae.fr/hal-03428436
}

Submitted on 15 Nov 2021

HAL is a multi-disciplinary open access archive for the deposit and dissemination of scientific research documents, whether they are published or not. The documents may come from teaching and research institutions in France or abroad, or from public or private research centers.
L'archive ouverte pluridisciplinaire HAL, est destinée au dépôt et à la diffusion de documents scientifiques de niveau recherche, publiés ou non, émanant des établissements d'enseignement et de recherche français ou étrangers, des laboratoires publics ou privés.

\section{(1) (1) $\$$}

Distributed under a Creative Commons Attribution - NonCommercial - NoDerivatives $\mid 4.0$ 
1 Specificity of resistance and tolerance to cucumber vein yellowing virus in melon accessions

2 and resistance breaking with a single mutation in VPg

4 C. Desbiez ${ }^{1 *}$, M-L. Domingo Calap ${ }^{2}$, M. Pitrat ${ }^{3}$, C. Wipf-Scheibel ${ }^{1}$, G. Girardot ${ }^{1}$, I. Ferriol $^{2}$, J-J.

5 Lopez-Moya², H. Lecoq ${ }^{1}$

6

7 IINRAE, Unité de Pathologie Végétale, Domaine St Maurice, Allée des Chênes, CS60094,

884143 Montfavet cedex, France

$9 \quad{ }^{2}$ Center for Research in Agricultural Genomics CRAG, CSIC-IRTA-UAB-UB, Campus UAB-

10 Bellaterra, 08193 Cerdanyola del Vallès, Barcelona, Spain

11 IINRAE, Unité de Génétique et Amélioration des Fruits et Légumes, Domaine St Maurice, Allée

12 des Chênes, CS60094, 84143 Montfavet cedex, France

$13{ }^{*}$ Corresponding author: C. Desbiez; E-mail: cecile.desbiez@inrae.fr 


\section{Abstract}

18 Cucumber vein yellowing virus (CVYV) is an emerging virus on cucurbits in the Mediterranean

19 Basin, against which few resistance sources are available, particularly in melon. The melon

20 accession PI 164323 displays complete resistance to isolate CVYV-Esp, and accession HSD 2458

21 presents a tolerance, i.e. very mild symptoms in spite of virus accumulation in inoculated plants.

22 The resistance is controlled by a dominant allele $C v y-1^{1}$, while the tolerance is controlled by a

23 recessive allele $c v y-2$, independent from $C v y-1^{1}$. Before introducing the resistance or tolerance in

24 commercial cultivars through a long breeding process, it is important to estimate their specificity

25 and durability. Upon inoculation with eight molecularly diverse CVYV isolates, the resistance was

26 found to be isolate-specific since many CVYV isolates induced necrosis on PI 164323, whereas the

27 tolerance presented a broader range. A resistance-breaking isolate inducing severe mosaic on $\mathrm{PI}$

28164323 was obtained. This isolate differed from the parental strain by a single amino acid change

29 in the VPg coding region. An infectious CVYV cDNA clone was obtained, and the effect of the

30 mutation in the VPg cistron on resistance to PI 164323 was confirmed by reverse genetics. This

31 represents the first determinant for resistance-breaking in an ipomovirus. Our results indicate

32 that the use of the $C v y-1^{1}$ allele alone will not provide durable resistance to CVYV and that, if used

33 in the field, it should be combined with other control methods such as cultural practices and

34 pyramiding of resistance genes to achieve long-lasting resistance against CVYV.

36 Keywords: infectious clone, ipomovirus, tolerance, resistance-breaking, VPg, fitness 
39 Cucumber vein yellowing virus (CVYV) is an emerging virus on cucurbits in the Mediterranean

40 Basin. CVYV belongs to the genus Ipomovirus in the family Potyviridae. Its genetic organization is

41 similar to that of viruses in the genus Potyvirus, except that it encodes no helper component

42 protein (HC-Pro) but a duplicated P1 protein that replaces the HC-Pro functionally as a silencing

43 suppressor (Valli et al. 2006). CVYV is transmitted by the whitefly Bemisia tabaci in a semi-

44 persistent manner (Lecoq et al. 2000; Desbiez et al. 2019). First described in Israel in 1960, CVYV

45 is now present throughout the Middle East and the western Mediterranean Basin (Velasco et al.

46 2016). Surveys in Sudan have shown that the virus has also been present for decades in Sub-

47 Saharan Africa (Desbiez et al. 2019). CVYV induces symptoms of vein clearing and yellowing of the

48 leaves, as well as discoloration and sometimes cracking on fruits that make them unmarketable

49 (Navas-Castillo et al. 2014). As for many other viruses, control of CVYV relies on the control of

50 whitefly populations and the use of genetic resistance when available (Janssen et al. 2003; Gomez

51 et al. 2009). The use of resistant cultivars is a sustainable and environmentally-friendlyway of

52 controlling viruses but presents several limitations. First, resistance factors must be available in

53 the germplasm of the species of interest or wild relatives and introduced in high-yielding cultivars

54 through a time- and labor-consuming breeding process. Besides, upon large-scale deployment of

55 resistances in the field, their efficiency can be threatened because they happen to be too specific,

56 i.e. efficient only against a subset of the existing viral isolates, or broken through the evolution of

57 the pathogen (Garcia- Arenal and McDonald 2003; Kobayashi et al. 2014). Therefore, it is

58 important to estimate the potential durability of a resistance factor before using it in breeding 59 programs. 
60 Resistance to CVYV has been described in wild Cucumis species (C. prophetarum, C. africanus, C.

61 dipsaceus) (Marco et al. 2003) and in cucumber (Cucumis sativus) (Pico et al. 2003) with some

62 strain variability (Galipienso et al. 2013). In melon (Cucumis melo), after screening 1188 melon

63 accessions with a Spanish isolate of CVYV, five phenotypes were observed (Pitrat et al. 2012).

64 Most accessions displayed either susceptibility (mosaic and vein clearing symptoms) or very high

65 susceptibility (severe mosaic, yellowing and stunting), a few accessions showed systemic necrosis

66 followed by rapid plant death, one accession was tolerant (very mild mottle despite virus

67 accumulation in the plant), and one accession was resistant (no symptoms, no virus detection)

68 (Pitrat et al. 2012) (Figure 1).

69 In this work, we studied the specificity of the resistance and tolerance phenotypes in melon

70 cultivars against several CVYV isolates. We showed that the tolerance was efficient against a large

71 number of isolates, whereas the resistance was very specific and easily overcome by the virus

72 through an $\mathrm{E}$ to $\mathrm{K}$ point mutation at amino acid position 90 in the viral protein genome-linked

73 (VPg). We also explored the possible impact of this mutation on VPg conformation.

\section{Materials and methods}

\section{Melon accessions}

77 Melon accessions representative of the five phenotypes observed after infection with CVYV-Esp

78 (Pitrat et al. 2012) were used in the study: i) Védrantais, a Cantaloupe type from France, is

79 susceptible to CVYV-Esp, showing symptoms of vein clearing and mosaic; ii) Ouzbeque 2 from

80 Uzbekistan is highly susceptible with symptoms of severe mosaic, stunting and yellowing; iii)

81 accession HSD 93-20-A from Sudan exhibits necrotic symptoms with rapid death upon infection; 
iv) HSD 2458 from Sudan is tolerant to CVYV-Esp, i.e. the virus can be detected in inoculated plants

83 but the plants display only a very mild mottle ; and v) accession PI 164323 from India is resistant

84 to CVYV-Esp : no virus is detected and no symptoms are visible in inoculated plants. The resistance

85 was first observed after mechanical inoculation of the virus but it was shown to be also effective

86 after whitefly transmission (data not shown). Five to 10\% of the mechanically infected PI 164323

87 plants developed a top necrosis after inoculation (Figure 1).

$88 \mathrm{~F}_{1}, \mathrm{~F}_{2}$ and back-cross $(\mathrm{BC})$ progenies were obtained between the above mentioned accessions in order to study the inheritance of the different phenotypes (Pitrat et al. 2012). Three loci appeared

to be involved. At a first locus tentatively named Cucumber vein yellowing resistance (symbol

$91 \quad C v y-1)$, three alleles have been identified: $C v y-1^{+}$for susceptibility (present in Védrantais), $C v y-1^{1}$

92 controlling resistance in $\mathrm{PI} 164323$ and $\mathrm{Cvy}-1^{2}$ controlling necrosis in HSD 93-20-A. At an

93 independent second locus, the recessive allele cvy-2 present in HSD 2458 controls the tolerance.

94 And at a third locus, the allele Cvy-3, present in Ouzbeque 2, controls the highly susceptible type

95 of symptoms (Pitrat et al. 2012).

96 The five lines studied in this paper present the following genotypes: Védrantais $\left[C v y-1^{+} c v y-2^{+} C v y-\right.$

$\left.973^{+}\right]$, Ouzbeque $2\left[C v y-1^{+} c v y-2^{+} C v y-3\right]$, HSD $2458\left[C v y-1^{+} c v y-2 C v y-3^{+}\right]$, PI $164323\left[C v y-1^{1} c v y-2^{+}\right.$

98 Cvy-3], and HSD 93-20-A [Cvy-12 cvy-2+Cvy-3] (Pitrat et al. 2012).

101 Isolates CVYV-Esp, SU96-84, SU12-10, TN05-56, OM04-06, ISR, LIB and JOR are as described in 102 Desbiez et al. (2019). They originate from Spain, Sudan, Tunisia, Oman, Israel, Lebanon, and 103 Jordan, respectively, and are representative of the known molecular variability of CVYV (Desbiez 

et al. 2019). All isolates were stored as dried leaf material on calcium chloride or as frozen leaf

105 tissue in liquid nitrogen. For inoculations, dry or frozen plant tissues were first ground in $0.03 \mathrm{M}$ $\mathrm{Na}_{2} \mathrm{HPO}_{4}+0.2 \%$ diethyldithiocarbamate (DIECA). Activated charcoal and carborundum $(75 \mathrm{mg} / \mathrm{ml}$ each) were added before rub-inoculating the two cotyledons of young plantlets of cucumber cf. Beit Alpha. Symptomatic cucumber leaves were used for mechanical inoculation of each melon accession with the same protocol, using 5 or 10 young plantlets of each accession. A second inoculation was performedone week later on the first leaf of the same melon plantlets to increase

111 infection efficiency. Inoculated plants were kept in a quarantine greenhouse (C3 biosecurity

112 level). The presence of the virus at the plant apex, six weeks after inoculation, was assessed by 113 DAS-ELISA with a CVYV-specific antiserum (Desbiez et al. 2019) or by RT- PCR as described (Lecoq 114 et al. 2007). The experiment was repeated three times.

\section{Full-length sequencing of resistance breaking isolate CVYV-PI1}

117 After mechanical inoculation of CVYV-Esp on melon PI 164323, symptoms of top necrosis were 118 observed in 5 to $10 \%$ of the plants (Figure 1). In one instance, an axillary shoot developed that 119 showed severe mosaic symptoms. Back inoculations were performed on PI 164323 from mosaic120 showing plant material and the inoculated plants displayed mosaic symptoms. After five 121 successive passages on PI 164323, the mosaic-inducing variant CVYV-PI1 was stored as dried 122 material on calcium chloride and used for full-length sequencing. The complete sequence of 123 CVYV-PI1 was determined through Sanger sequencing as described by Desbiez et al. (2019). Full124 length sequences of CVYV-PI1 and CVYV-Esp were aligned with ClustalW included in MEGA6 125 (Tamura et al. 2013) and compared manually. 
127 Total RNA was extracted from a young plant of cucumber cv. Beit Alpha inoculated with CVYV-

128 Esp using TRI-reagent (Molecular Research Center, Cincinnati, OH). The precise sequence of the

129 5' extremity from CVYV-Esp was reassessed by 5'-RACE (Ferriol et al. 2018). The genome of CVYV-

130 Esp was amplified in five overlapping fragments of 1.2 to $1.8 \mathrm{~kb}$ through a two-step RT-PCR using 131 a high-fidelity Pfu DNA polymerase for PCR and specific primers (Supplementary table S1) as

132 described (Desbiez et al. 2012). Two introns were added by fusion PCR to fragments 2 and 3, in 133 the $\mathrm{P} 3$ and $\mathrm{Cl}$ coding regions, respectively. The five final fragments were purified from agarose 134 gel, mixed with a linearized vector derived from pAGUS1 and used for transformation of 135 competent Saccharomyces cerevisiae YHP 501 cells as described (Desbiez et al. 2012), before 136 plating on CAU selective medium. The yeast colonies were then grown in CAU liquid medium, 137 yeast DNA was extracted as described (Desbiez et al. 2012) and used to transform 138 electrocompetent Escherichia coli $\mathrm{DH} 5 \alpha$ bacteria. Bacterial plasmid DNA was extracted by 139 alkaline lysis and a screening was performed by restriction enzyme analysis. Since the yields of 140 bacterial DNA were very low, $0.5 \mu$ of plasmid DNA were submitted to rolling circleamplification 141 (RCA) using the TempliPhi kit (GE Healthcare) according to the manufacturer's manual.One $\mu$ l 142 of RCA product was then used for restriction analysis. Inoculation was performed by biolistics 143 using a GeneGun according to Gal-On et al. (1995), on the cotyledons of eight cucumber Beit 144 Alpha plantlets. Briefly, $30 \mu \mathrm{l}$ of plasmid DNA, or $5 \mu \mathrm{l}$ RCA product $+25 \mu \mathrm{l}$ distilled water, were 145 mixed with $30 \mu \mathrm{l}$ of tungsten $\mathrm{M} 20$ at $50 \mathrm{mg} / \mathrm{ml}$ in $50 \%$ glycerol and $30 \mu \mathrm{l}$ of $\mathrm{Ca}\left(\mathrm{NO}_{3}\right)_{2} 1.25 \mathrm{M}, \mathrm{pH}$ 146 8. After 5 minutes at room temperature, a short centrifugation was performed and $60 \mu$ of the supernatant were removed. Three $\mu \mathrm{l}$ of the remaining mix were used for the bombardment of 
Page 8 of 25

C. Desbiez

Phytopathology

148 each plant. Three different DNA preparations were used: (1) plasmid DNA without RCA

149 amplification (2) plasmid DNA amplified by RCA and digested with SnaBI that cuts only once in

150 the vector, in order to inoculate monomers of the construct rather than the very long

151 amplification products of the RCA reaction, and (3) plasmid DNA amplified by RCA without post-

152 RCA treatment. The plants were kept in a quarantine greenhouse (C3 biosecurity level) until

153 symptom development. The full-length sequence of clone 3.1 was established as described

154 (Desbiez et al. 2019) and compared to the original sequence of CVYV-Esp.

156 Site-directed mutagenesis in the VPg of CVYV-Esp

157 In order to validate the effect of the VPg mutation on CVYV infectivity in PI 164323, site-directed

158 mutagenesis was performed on the CVYV-Esp infectious clone CVYV 3.1. RT-PCR was performed

159 on the cloned DNA with mutagenic primers CV-mutaVPg2-F (5'-

160 GgAGATTTCAAAGGGAAAGTCTGGGAAACAAAAGACATGGA-3') and CV-mutaVPg-R2 (5'-

161 CCATGTCTTTTGTTTCCCAGACTTICCCTTTGAAATCTCCAACTG-3'). The underlined residue

162 indicates the position of the mutation (position 5962 in the genome and 6355 in the intron-

163 containing clone). Two fragments of $1300 \mathrm{nt}$ and $1900 \mathrm{nt}$, respectively, overlapping at the

164 position of the mutation, were amplified by RT-PCR with the following primers (1) CVYV-GRMKP-

5' (5'- AGtgGATCCGgRAGGATGAARCCAGGNAC-3') + CV-mutaVPg2-R, and (2) CV-mutaVPg-F +

CVYV-VVDNT-3'(5'- CCAGGATCCATGAGGGTATTGTCCACCAC-3').

167 Since the expression level of CVYV-Esp infectious clone in $E$. coli was very low, clone 3.1 was

168 submitted to RCA with the TempliPhi kit according to the manufacturer's manual before 169 digestion with restriction enzyme Ndel that cuts at positions 5210 and 8140 in the intron- 
170 containing CVYV clone. The 12.7-kbp resulting vector DNA as well as the two PCR fragments were

171 purified from gel and used for transformation of competent S. cerevisiae YHP 501 cells as

172 described (Desbiez et al. 2012). After growth on CAU medium, yeast DNA was extracted and used

173 to transform electrocompetent E. coli $\mathrm{DH} 5 \alpha$ bacteria. Bacterial plasmid DNA was extracted by

174 alkaline lysis and a screening was performed by restriction enzyme analysis. The presence of the

175 expected E90K mutation in the VPg was checked by amplification with primers CVYV-VPg-F (5'-

176 GCAGGAGTCATCACGATAAC-3') and CVYV-6250-R (5'-ARCAATTGCGGTTTCAGCGAC-3') followed

177 by Sanger sequencing of the targeted area. Positive clones ( $0.5 \mu$ I DNA extracted by alkaline lysis)

178 were amplified by RCA. One $\mu$ of RCA product was used for inoculation by biolistics on the

179 cotyledons of cucumber Beit Alpha plantlets.

\section{Infectivity of CVYV-VPg-C1}

182 One infectious clone containing the VPg mutation, CVYV-VPg-C1, was inoculated by GeneGun to 183 five plantlets of cucumber cv. Beit Alpha. Leaf tissue of symptomatic plants was used for 184 mechanical inoculation of 5 or 10 plantlets of cucumber Beit Alpha and melons cv. Védrantais, PI 185 164323, Ouzbeque 2, HSD 93-20-A and HSD 2458. The plants were kept in a quarantine 186 greenhouse until symptom development. Six weeks after inoculation, all asymptomatic plants 187 were tested by DAS-ELISA for the presence of CVYV. The experiment was repeated 3 times.

\section{Comparison of VPg sequences and their disorder profiles among CVYV and potyvirid isolates.}

190 The VPg sequences of 11 CVYV isolates were retrieved from GenBank (accessions AY578085, 191 JF460793, KT276369, MK777988-MK777995). Nucleotide and translated amino acid sequences 
Page 10 of 25

C. Desbiez

Phytopathology

192 of these isolates and of CVYV-PI1 were aligned with ClustalW. Alignments were also performed

193 with the VPg amino acid sequences of other ipomoviruses: coccinia mottle virus (CocMoV,

194 YP_009272707), squash vein yellowing virus (SqVYV, YP_001788991, AEV45694, ALN38790,

195 AOY33888), cassava brown streak virus (CBSV,YP_007027011), Ugandan cassava brown streak

196 virus (UCBSV, YP_004063980) and sweetpotato mild mottle virus (SPMMV, NP_734290).

197 Four methods were used to predict the intrinsic disorder of CVYV VPg and the impact of the

198 mutation on this disorder: (1) Disopred (http://bioinf.cs.ucl.ac.uk/disopred), (2) DisEMBL

199 (http://dis.embl.de), (3) GlobProt (http://globplot.embl.de), and (4) PONDR ${ }^{\circledR}$

200 (http://www.pondr.com), as described by Desbiezet al. (2014). As a comparison, VPg sequences

201 of three different ipomoviruses (SqVYV, CBSV and UCBSV) and of four potyviruses (potato virus Y,

202 zucchini yellow mosaic virus, papaya ringspot virus and turnip mosaic virus) were analysed with

$203 \mathrm{PONDR}^{\circledR}$.

204

205 Results

206 Isolate specificity of CVYV resistance and tolerance

207 Upon inoculation of the reference susceptible accession Védrantais $\left[C v y-1^{+} c v y-2^{+} C v y-3^{+}\right]$, the

208 eight CVYV isolates tested induced mosaic and vein banding symptoms (Table 1); isolates CVYV-

209 JOR and CVYV-Su96-84 also induced some stunting. Accession Ouzbeque 2 [Cvy-1+ $c v y-2^{+} C v y-3$,

210 carrying the high susceptibility allele $C v y-3$, displayed severe symptoms of mosaic and stunting

211 upon inoculation with the different isolates. On HSD 93-20-A [Cvy-1 $\left.{ }^{2} c v y-2^{+} \mathrm{Cvy}-3\right]$ carrying the

$212 \mathrm{Cvy}^{2}$ allele responsible for lethal necrosis upon inoculation with CVYV-Esp, all isolates except

213 SU96-84 induced 100\% top necrosis or systemic necrosis. Upon inoculation with SU96-84, in most 
214 cases no symptoms were visible and no virus was detected by DAS-ELISA but occasionally

215 systemic necrosis was observed. Accession HSD $2458\left[C v y-1^{+} c v y-2 C v y-3^{+}\right]$carrying the $c v y-2$

216 allele conferring tolerance to CVYV-Esp was tolerant and displayed only very mild mottle

217 symptoms upon inoculation with the different isolates, even though the Jordanian and Oman

218 isolates were more severe than the others. The melon accession PI $164323\left[\mathrm{Cvy}-1^{1} c v y-2^{+} \mathrm{Cvy}-3\right]$

219 carrying the resistance allele Cvy-1 ${ }^{1}$ displayed complete resistance with no visible symptoms and

220 no virus detection by DAS-ELISA to isolate CVYV-SU12-10. Upon inoculation with CVYV-Esp and

221 CVYV-Isr, most inoculated plants $(>90 \%, \mathrm{n}>30)$ displayed no symptoms and no virus accumulation

222 at the systemic level (Table 1), even though a low proportion of the inoculated plants (5 to $10 \%)$

223 developed top necrosis, followed by plant death. For the five other isolates CVYV-JOR, CVYV-

224 SU96-84, CVYV-TN05-56, CVYV-OM04-06 and CVYV-LIB, nearly all inoculated plants showed lethal

225 top necrosis (Table 1 ; Figure 1).

\section{Full-length sequencing of CVYV-Esp and the resistance-breaking variant CVYV-PI1}

228 An evolved isolate CVYV-PI1, developing severe mosaic symptoms on PI 164323, was obtained

229 after mechanical inoculation of CVYV-Esp. The full-length sequences of CVYV-PI1 and CVYV-Esp

230 were obtained(Desbiez et al. 2019). The accurate sequence of the 5' extremity of CVYV-Esp was

231 obtained by using 5'-RACE, indicating that the CVYV sequence available before was truncated and

232 the first $17 \mathrm{nt}$ were missing. The sequence of CVYV-Esp sequence presented an A-rich 5' extremity

233 as expected for a potyvirid, and the first $15 \mathrm{nt}$ were identical to those of the SqVYV reference

234 isolate (accession NC_010521). Compared to CVYV-Esp, three mutations were found in CVYV-PI1,

235 at positions 5055, 5962 and 7620. Mutations 5055 (TTA/TTG) and 7620 (CGC/CGT) were 
Page 12 of 25

C. Desbiez

Phytopathology

236 synonymous, whereas mutation 5962 (GAA/AAA, $\mathrm{G}_{5962} \mathrm{~A}$ ) caused an amino acid change at position

23790 in the viral VPg, from glutamicacid $(E)$ to lysine $(K)\left(E_{90} K\right)$.

238

239 Infectious cDNA clone of CVYV-Esp

240 After amplification of the CVYV-Esp genome and yeast transformation, clones with the 241 expected size and restriction profiles were obtained but the level of expression of plasmid DNA

242 in E. coli was very low, and RCA amplification was performed to enhance the plasmid 243 concentration. After GeneGun inoculation on cucumber cv. Beit Alpha, $100 \%$ of inoculated plants

244 with clone 3.1 showed symptoms of vein clearing two weeks after inoculation with the RCA-

245 amplified plasmid, whether or not it was digested with SnaBI, showing that direct GeneGun

246 inoculation of very long RCA products was as efficient as inoculation with the $15 \mathrm{kbp}$ linearized

247 plasmid. In contrast, no infection was observed with inoculation of the plasmid without RCA

248 amplification. The full-length sequence of clone 3.1 was determined, and it differed from the 249 sequence obtained ten years earlier for the original field isolate by 26 mutations including 7 non-

250 synonymous located in the P1 (3 mutations), NIb (2 mutations), Cl and CP (1 mutation each).

251 There was no non-synonymous mutation in the VPg.

\section{Effect of the VPg EgoK mutation on CVYV infectivity and symptom expression}

254 The $\mathrm{G}_{5962} \mathrm{~A}\left(\mathrm{VPg} \mathrm{E}_{90} \mathrm{~K}\right.$ ) mutation was introduced in the CVYV 3.1 clone by PCR mutagenesis, yielding 255 the mutated clone CVYV-VPg-C1. The presence of the mutation in CVYV-VPg-C1 clone was 256 confirmed by partial sequencing. After amplification by RCA and inoculation by GeneGun of clone 257 CVYV-VPg-C1, 5/5 inoculated Beit Alpha cucumber plants showed symptoms of vein clearing and 

mosaic indistinguishable from those of CVYV 3.1. After mechanical inoculation on PI 164323, all

259 inoculated plants displayed severe mosaic and yellowing symptoms similar to those induced by 260 the natural resistance-breaking isolate CVYV-PI1 (Table 1). Both CVYV-PI1 and CVYV-VPg-C1 261 induced similar symptoms as CVYV-Esp on the melon accessions HSD 2458 (tolerance), Ouzbeque 2622 (severe symptoms of mosaic and stunting) and HSD93-20-A (lethal top necrosis) (Table 1). On 263 Védrantais, CVYV-PI1 induced mottle or mosaic symptoms milder than those of CVYV-Esp and 264 CVYV 3.1, and the cloned mutant CVYV-VPg-C1 induced only very mild mottle (Table 1) although the virus was readily detected using DAS-ELISA.

Diversity and structure of the VPg coding region of CVYV and other ipomoviruses

The amino acid VPg sequences of 11 CVYV isolates and the evolved variant CVYV-PI1 were aligned and compared. There was no extensive sequence polymorphism in the VPg coding region for

270 CVYV (183 aa for all isolates) (Figure 2a). Most CVYV isolates had an E at amino acid position 90

271 in the VPg, except CVYV-ISR and CVYV-ISM (sharing identical VPg sequences) that had a D. Among

272 the 11 CVYV sequences excluding CVYV-PI1, 14 non-synonymous mutations were present in the

273 VPg coding region, nine of which were observed in only one isolate. Ten mutations were in the 274 central part of the VPg between aa 90 and 137 out of 183 . CocMoV, closely related molecularly 275 to CVYV, displayed $\sim 75 \%$ amino acid identity in the VPg with different CVYV isolates. It had a $Q$ at 276 the position corresponding to CVYV VPg 90 , immediately followed by an $\mathrm{E}$, and a K at position VPg93

277 instead of the E present in all CVYV isolates (Figure 2a). Melon accession PI 164323 was 278 susceptible to the Su12-25 isolate of CocMoV in mechanical inoculation ( $\mathrm{H}$. Lecoq, unpublished).

279 The other ipomoviruses displayed between $30 \%$ and $50 \%$ aa conservation inthe VPg with CVYV, 
280 without conservation at or around the $E_{5962}$ position (Figure 2a).

281 Based on PONDR prediction, the central part of CVYV VPg where the resistance-breaking mutation 282 was located appeared as a highly ordered region, and the $\mathrm{E}_{90} \mathrm{~K}$ mutation, despite the change from 283 a negatively charged glutamic acid to the positively charged lysine, did not have a strong effect 284 on its disorder profile (Figure $2 b$ ). The VPg disorder profile of CVYV was very different from that 285 of the potyviruses PVY, ZYMV, PRSV and TuMV (Supplementary figure S2), where the central 286 region of the VPg was confirmed as an intrinsically disordered domain (Supplementary figure S2).

287 The disorder profiles of the ipomoviruses CVYV, SqVYV, CBSV, and UCBSV were very variable, the 288 central domain being either ordered or disordered, with contrasted situations even for the closely 289 related CBSV and UCBSV (Supplementary figure S2), suggesting that the VPg interaction patterns 290 between potyviruses and ipomoviruses, and also between different ipomoviruses are not 291 conserved.

\section{Discussion}

294 In this work, we found that resistance to CVYV present in melon accession PI 164323 and 295 conferred by the allele $C v y-1^{1}$ was isolate-specific since only some isolates failed to infect, 296 whereas others induced a rapid and lethal top necrosis. Besides, the resistance to CVYV-Esp could 297 be overcome through a point mutation in the virus genome, resulting in an $\mathrm{E}$ to $\mathrm{K}$ amino acid 298 change $\left(\mathrm{E}_{90} \mathrm{~K}\right)$ in the viral VPg. We validated the effect of that mutation by reverse genetics using 299 a newly-developed infectious cDNA clone of CVYV. Previous attempts to obtain infectious clones 300 of CVYV were unsuccessful, probably due to the fact that the sequences available so far lacked 17 301 nts at their 5' extremity, including the first four "As" required for potyvirid infectivity (Simon- 
Buela et al. 2000). Despite the presence of two introns in the $\mathrm{P} 3$ and $\mathrm{Cl}$ coding regions of the

303 CDNA, the yield of CVYV-containing plasmids were very low in E. coli, probably in relation to the

304 toxicity of P1a or P1b proteins in bacteria. No infection was obtained after direct biolistic

305 inoculation of the plasmid, indicating that the threshold concentration of plasmid DNA for

306 infectivity was not reached. For potyviruses, less than $0.1 \mathrm{ng}$ plasmid DNA can be sufficient for

307 high infectivity after bombardment (Gal-On et al. 1995), but it seems more DNA may be required

308 for CVYV. Indeed, CVYV is generally less efficiently transmitted than cucurbit-infecting potyviruses

309 in mechanical inoculation (H. Lecoq, unpublished). The use of RCA prior to inoculation improved

310 the infectivity of the plasmid. Resistance-breaking mutants, both the natural CVYV-PI1 and the

311 cloned CVYV-VPg-C1, induced severe mosaic symptoms on PI 164323. Such severe symptoms

312 could be expected since PI 164323, besides the broken Cvy-1 ${ }^{1}$ resistance allele, possesses the

313 Cvy-3 "high susceptibility" allele also present in Ouzbeque 2 (Pitrat et al. 2012).

314 The E to K mutation at aa position 90 in the VPg of CVYV-VPg-C1 was sufficient to induce resistance

315 breaking in PI 164323. Indeed, contrary to other pathogens, most situations of resistance breaking

316 in plant viruses are related to point mutations rather than indels or loss of expression (Sacristan

317 and Garcia-Arenal 2008). This is probably due to the constraints of virus genomes where all

318 proteins are required for infectivity and are frequently multifunctional (Revers and Garcia 2015).

319 The $\mathrm{E}_{90} \mathrm{~K}$ mutation in the VPg resulted in charge change in the protein, which probably affects its

320 interaction with so far undetermined plant or virus factors. The area where the mutation took

321 place appears as highly ordered, and the mutation does not seem to modify deeply the level of

322 disorder of the protein (Figure $2 b)$.

323 Surprisingly, although the resistance related to $C v y-1^{1}$ was efficient only against some CVYV 
324 isolates that display an E or a D at position 90 in the VPg, all the other isolates tested had an E at

325 position 90 and presented few mutations in the direct vicinity of this site. CVYV-JOR had a V to I

326 mutation at position 91, and OM04-06 had an E to $\mathrm{G}$ mutation at position 101, but no common

327 mutation was detected. Top necrosis was frequently observed upon infection with different CVYV

328 isolates, which might be considered as a systemic hypersensitive response (Abebe et al. 2021). As

329 described for cucumber mosaic virus, a small decrease in the level of resistance induction could

330 change a hypersensitive response (not visible in PI 164323 but that may take place at the cellular

331 level) to systemic necrosis that may account for the low and variable frequency of top necrosis in

332 PI 164323 upon inoculation with CVYV-Esp. Determinants for the top necrosis response may thus

333 be different from those involved in the bona fide resistance breaking observed for CVYV-PI1. PI

334164323 was also observed to display occasionally top necrosis even in the absence of virus

335 infection, although the mechanisms involved are not known (M. Pitrat, unpublished).

336 Mutations in the VPg have been associated with resistance-breaking virus isolates in several plant-

337 virus interactions (Truniger and Aranda 2009), notably among potyviruses where direct

338 interaction between the VPg and the plant translation initiation factors elF4E and/or elF(iso)4E is

339 required for infectivity (Le Gall et al. 2011; de Oliveira et al. 2019). In these cases, the resistance

340 is recessive (Truniger and Aranda 2009 ; Revers and Garcia 2015), and mutations in the highly

341 disordered central region of the VPg affect the direct interaction with elF4E (Ala-Poikela et al.

3422019 ; Charon et al. 2018). Melon lines silenced for elF4E showed resistance to several potyviruses

343 and also to CVYV (Rodriguez-Hernandez et al. 2012), suggesting that the resistance mechanisms

344 could be related in both cases to a lack of functional interaction between virus VPg and plant

345 elF4E. Cucumbers with the elF4E gene disrupted by CRISPR/Cas9 technology were also immune 
346 to CVYV, the resistance being recessive as for potyviruses (Chandrasekaran et al. 2016). Contrary

347 to most potyvirus resistance, resistance to CVYV in melon PI 164323 appeared to be controlled

348 by a dominant allele $C v y-1^{1}$ (Pitrat et al. 2012), which does not fit with a hypothesis of the

349 resistance allele being a plant component, e.g. elF4E, required for infectivity. There was no amino

350 acid difference in the elF4E between Védrantais and PI 164323 (C. Dogimont, pers. comm.). PI

351164323 presented a nonsynonymous mutation in the elF(iso)4E protein but the same mutation

352 was also present in accession 90625 (C. Dogimont, pers. comm.) that shows no resistance to

353 CVYV-Esp (Pitrat et al. 2012). Thus, there was no obvious correlation between elF4E or elF(iso)4E

354 coding sequences and resistance to CVYV. Besides elF4E, the VPg of potyviruses interacts with

355 several host and virus proteins (Jiang and Laliberté 2011). Potyvirus VPg contributes directly to

356 inhibiting plant antiviral silencing response (Rajamäki et al. 2014 ; Cheng and Wang 2017), and it

357 also interacts with the viral silencing suppressor HC-Pro (Jiang and Laliberté 2011). CVYV VPg may

358 play a role in silencing suppression as well, either by itself or cooperatively through interaction

359 with other viral products including the silencing suppressor P1b that functionally replaces the

360 potyviral HC-Pro (Valli et al. 2006). These properties might be affected in the resistance-breaking

361 mutant. Alternatively, CVYV VPg may be recognized as an avirulence factor by a host resistance

362 gene in PI 164323, inducing an effector-triggered immune response leading to complete

363 resistance or to top necrosis depending on the timing or efficiency of the reaction. More studies

364 will be needed to understand the nature of the Cvy 1 gene and all the details of the interaction

365 between CVYV and melon.

366 Since the resistance conferred by $C_{v y} 1^{1}$ is isolate-specific, it should not be used in the field 367 in areas where necrosis-inducing isolates are present. A single mutation, corresponding to an A 
to $\mathrm{G}$ transition in the virus genome, was sufficient to induce resistance breaking in PI 164323.

369 This constitutes the least favorable situation for resistance durability (Fabre et al. 2009).

370 Resistance breaking might have a fitness cost, as observed for other plant-virus interactions

371 (Desbiez et al. 2003 ; Janzac et al. 2010), which could contribute to preserving resistance

372 durability through optimized management of the resistance deployment (Rimbaud et al. 2021).

373 However, this may not be sufficient to ensure satisfactory durability of the resistance in the field,

374 and thus a durable control of CVYV, without being associated with other control measures.

375 Pyramiding the resistance and tolerance genes (Mundt 2018) and eliminating the Cvy-3 "super-

376 susceptibility" allele may lead to more efficient and durable control to this damaging virus

377 against which very few resistances are available so far in melon.

379 Acknowledgements:

380 We thank the Experimental Infrastructure team of INRAE-Montfavet for their help in the 381 greenhouse experiments. We thank D. Besombes for obtaining part of the melon accessions and 382 crosses. We thank Dr C. Dogimont for the information about melon elF4E and elF(iso)4E.

\section{Ethical statement:}

385 This research did not involve any human participants and/or animals. The authors declare that 386 they have no conflict of interest

References

389 Abebe, D. A., van Bentum S., Suzuki, M., Ando, S., Takahashi, H., and Miyashita, S. 2021. Plant 

death caused by inefficient induction of antiviral R-gene-mediated resistance may function as a 391 suicidal population resistance mechanism. Comm. Biol. 4 :947.

392 Ala-Poikela, M, Rajarnaki, M-L, and Valkonen, J. P. T. 2019. A Novel Interaction Network Used by 393 Potyviruses in Virus-Host Interactions at the Protein Level. Viruses-Basel 11: 1158.

394 Chandrasekaran, J., Brumin, M., Wolf, D., Leibman, D., Klap, C., Pearlsman, M., Sherman, A., 395 Arazi, T., and Gal-On, A. 2016. Development of broad virus resistance in non-transgenic cucumber 396 using CRISPR/Cas9 technology. Mol. Plant Pathol. 17: 1140-1153.

397 Charon, J., Barra, A., Walter, J., Millot, P., Hebrard, E., Moury, B., and Michon, T. 2018. First 398 Experimental Assessment of Protein Intrinsic Disorder Involvement in an RNA Virus Natural 399 Adaptive Process. Mol. Biol. Evol. 35: 38-49.

400 Cheng, X., and Wang A. 2017. The Potyvirus Silencing Suppressor Protein VPg Mediates 401 Degradation of SGS3 via Ubiquitination and Autophagy Pathways. J. Virol. 91: e01478-16.

402 de Oliveira, L. C., Volpon, L., Rahardjo, A. K., Osborne, M. J., Culjkovic-Kraljacic, B., Trahan, C., 403 Oeffinger, M., Kwok, B. H., and Borden, K. L. B. 2019. Structural studies of the elF4E-VPg complex 404 reveal a direct competition for capped RNA: Implications for translation. Proc. Natl. Acad. Sci. USA 405 116: 24056-24065.

406 Desbiez, C, Gal-On, A., Girard, M., Wipf-Scheibel, C., and Lecoq, H. 2003. Increase in Zucchini 407 yellow mosaic virus symptom severity in tolerant zucchini cultivars is related to a point mutation 408 in P3 protein and is associated with a loss of relative fitness on susceptible plants. Phytopathology 409 93:1478-1484.

410 Desbiez, C., Caciagli, P., Wipf-Scheibel, C., Millot, P., Ruiz Garcia, L., Marian, D., Dafalla, G., and 411 Lecoq, H. 2019. Evidence for long-term prevalence of cucumber vein yellowing virus in Sudan and 
412 genetic variation of the virus in Sudan and the Mediterranean Basin. Plant Pathol. 68:1268-1275.

413 Desbiez, C., Chandeysson, C., Lecoq, H., and Moury, B. 2012. A simple, rapid and efficient way to 414 obtain infectious clones of potyviruses. J. Vir. Meth. 183: 94-97.

415 Desbiez, C., Chandeysson, C., and Lecoq, H. 2014. A short motif in the N-terminal part of the coat 416 protein is a host-specific determinant of systemic infectivity for two potyviruses. Mol. Plant 417 Pathol. 15:217-221.

418 Fabre, F., Bruchou, C., Palloix, A., and Moury, B. 2009. Key determinants of resistance durability 419 to plant viruses: Insights from a model linking within- and between-host dynamics. Virus Res. 141: $420 \quad 140-149$.

421 Ferriol, I., Domingo-Calap, M.-L., Desbiez, C., and Lopez-Moya, J.-J. 2018. Determination of the 422 complete $5^{\prime}$-UTR of the ipomovirus Cucumber vein yellowing virus (CVYV), and its relevance for 423 infectivity in cucurbit plants. in: XIX Congreso de la Sociedad Española de Fitopatología, Toledo, 424 Spain.

425 Gal-On, A., Meir, E., Huet, H., Hua, W.J., Raccah, B., and Gaba, V. 1995. Particle bombardment 426 drasticallyincreases the infectivity of cloned DNA of zucchini yellow mosaic potyvirus. J. Gen. Virol.

$427 \quad 76: 3223-3227$.

428 Galipienso, L., Janssen, D., Rubio, L., Aramburu, J., and Velasco, L. 2013. Cucumber vein yellowing 429 virus isolate-specific expression of symptoms and viral RNA accumulation in susceptible and 430 resistant cucumber cultivars. Crop Protect. 43:141-145.

431 Garcia-Arenal, F., and McDonald, B. 2003. An analysis of the durability of resistance to plant 432 viruses. Phytopathology 93:941-952.

433 Gomez, P., Rodriguez-Hernandez, A.M., Moury, B., and Aranda, M.A. 2009. Genetic resistance for 
434 the sustainable control of plant virus diseases: breeding, mechanisms and durability. Eur. J.

435 Plant Pathol. $125: 1-22$.

436 Janssen, D., Ruiz, L., Cano, M., Belmonte, A., Martin, G., Segundo, E., and Cuadrado, I.M. 2003.

437 Physical and genetic control of Bemisia tabaci-transmitted cucurbit yellow stunting disorder virus

438 and cucumber vein yellowing virus in cucumber. Bull. OILB/SROP 26:101-106.

439 Janzac, B, Montarry, J., Palloix, A., Navaud, O., and Moury, B. 2010. A point mutation in the

440 polymerase of Potato virus $Y$ confers virulence towards the Pvr4 resistance of pepper and a high

441 competitiveness cost in susceptible cultivar. Mol. Plant-Microbe Interact. 23:823-830.

442 Jiang, J., and Laliberté, J.-F. 2011. The genome-linked protein VPg of plant viruses: a protein with

443 many partners. Curr. Opin. Virol. $1: 347-354$.

444 Kobayashi, K., Sekine, K.T., and Nishiguchi, M. 2014. Breakdown of plant virus resistance: can we

445 predict and extend the durability of virus resistance? J. Gen. Plant Pathol. 80 :327-336.

446 Le Gall, O., Aranda, M.A., and Caranta, C. 2011. Plant Resistance to Viruses Mediated by

447 Translation Initiation Factors. In: Recent Advances in Plant Virology, pp. 177-194.

448 Lecoq, H., Desbiez, C., Delecolle, B., Cohen, S., and Mansour, A. 2000. Cytological and molecular 449 evidence that the whitefly-transmitted Cucumber vein yellowing virus is a tentative member of 450 the family Potyviridae. J. Gen. Virol. 81: 2289-2293.

451 Lecoq, H., Dufour, O., Wipf-Scheibel, C., Girard, M., Cotillon, A.-C., and Desbiez, C. 2007. First 452 report of Cucumber vein yellowing virus in melon in France. Plant Dis. 91: 909.

453 Marco, C.F., Aranda, M.A., Montoro, T., and Gómez-Guillamón, M.-L. 2003. Evaluation of several 454 accessions and wild relatives of Cucumis melo against Cucumber Vein Yellowing Virus (CVYV).

455 Cucurbit Genet. Coop. Ann. Rep. 26: 7-8. 
456 Mundt, C. 2018. Pyramiding for resistance durability: theory and practice. Phytopathology $457 \quad$ 108:792-802.

458 Navas-Castillo, J., Lopez-Moya, J.J., and Aranda, M.A. 2014. Whitefly-transmitted RNA viruses that 459 affect intensive vegetable production. Ann. Appl. Biol. 165:155-171.

460 Pico, B., Villar, C., and Nuez, F. 2003. Screening Cucumis sativus landraces for resistance to 461 cucumber vein yellowing virus. Plant Breeding 122:426-430.

462 Pitrat, M., Wipf-Scheibel, C., Besombes, D., Desbiez, C., and Lecoq, H. 2012. Resistance of melon 463 to Cucumber Vein Yellowing Virus (CVYV). Cucurbitaceae 2012: Proceedings of the Xth Eucarpia 464 Meeting on Genetics and Breeding of Cucurbitaceae, 157-164.

465 Rajamaki, M. L., Streng, J., and Valkonen, J. P. T. 2014. Silencing Suppressor Protein VPg of a 466 Potyvirus Interacts With the Plant Silencing-Related Protein SGS3. Mol. Plant-Microbe Interact. $467 \quad 27: 1199-1210$.

468 Revers, F., and Garcia, J.A. 2015. Molecular biology of potyviruses. Adv Virus Res 92:101-199.

470 Rimbaud, L., Fabre, F., Papaix, J., Moury, B., Lannou, C., Barrett, L.G., and Thrall, P.H. 2021. Models

471 of plant resistance deployment. Ann. Rev. Phytopathol. 59, doi: 10.1146/annurev-phyto-020620472122134.

473 Rodriguez-Hernandez, A.M., Gonsalvez, B., Sempere, R.N., Burgos, L., Aranda, M.A., and Truniger, 474 V. 2012. Melon RNA interference (RNAi) lines silenced for Cm-elF4E show broad virus resistance. 475 Mol. Plant Pathol. 13:755-763.

476 Sacristan, S., and Garcia-Arenal, F. 2008. The evolution of virulence and pathogenicity in plant 477 pathogen populations. Mol. Plant Pathol. 9:369-384.

478 Simon-Buela, L., Osaba, L., Garcia, J.A., and Lopez-Moya, J.J. 2000. Preservation of 5'-end integrity 
479 of a potyvirus genomic RNA is not dependent on template specificity. Virology 269:377-382.

480 Tamura, K., Stecher, G., Peterson, D., Filipski, A., and Kumar, S. 2013. MEGA6: Molecular

481 Evolutionary Genetics Analysis version 6.0. Mol. Biol. Evol. 30: 2725-2729.

482 Truniger, V., and Aranda, M.A. 2009. Recessive resistance to plant viruses. Adv. Virus Res. 75:119-

483159.

484 Valli, A., Martin-Hernandez, A.M., Lopez-Moya, J.-J., and Garcia, J.A. 2006. RNA silencing 485 suppression by a second copy of the P1 serine protease of Cucumber vein yellowing ipomovirus, 486 a member of the family Potyviridae that lacks the cysteine protease HCPro. J. Virol. 80 :1005548710063.

488 Velasco, L., Salem, N., Willemsen, A., Lapidot, M., Mansour, A.N., Rubio, L., and Galipienso, L. 489 2016. Genetic variation and evolutionary forces shaping Cucumber vein yellowing virus 490 populations: risk of emergence of virulent isolates in Europe. Plant Pathol. 65:847-856. 
Table 1 : Symptoms induced by CVYV isolates on melon accessions.

$M$ : mosaic; $M+$ : severe mosaic ; $M-$ : mild mosaic; mo = very mild mottle; St: stunting ; VB : vein

banding; TN : top necrosis followed by plant death; nec : systemic necrosis; 0 : no symptoms and

519 Cvy3. The alleles involved in the accession behaviour upon inoculation with CVYV-Esp are 520 underlined.

521 Symptoms indicated in brackets were observed occasionally on the inoculated plants. The dashed 522 line separates the field isolates from the evolved CVYV-PI1 and the viruses obtained from 523 infectious clones (CVYV 3.1 and CVYV-VPg-C1).

Melon accession and genotype

Védrantais PI 164323 HSD 93-20-A HSD 2458 Ouzbeque 2

$\left(\mathrm{Cvy}-1^{+}, \mathrm{cvy}-2^{+}, \quad\left(\underline{\mathrm{Cvy}-1^{1}}, \mathrm{cvy}-\quad\left(\underline{\mathrm{Cvy}-1^{2}}, \mathrm{cvy}-2^{+}, \quad\left(\mathrm{Cvy}-1^{+}, \underline{\mathrm{cvy}}-\quad\left(\mathrm{Cvy}-1^{+}, \mathrm{cvy}-2^{+}\right.\right.\right.\right.\right.$,

\begin{tabular}{|c|}
\hline (vvy-3+) \\
\hline
\end{tabular}

$\begin{array}{lllll}\text { CVYV-Esp } & \mathrm{M} & \mathrm{T}(\mathrm{TN}) & \mathrm{TN} & \mathrm{M}+\end{array}$

$\begin{array}{lllll}\text { CVYV-ISR } & \text { M, VB } & \text { (TN) } & \text { Mnec (TN) }\end{array}$

$\begin{array}{llllll}\text { CVYV-JOR } & \mathrm{M}+\text {, St } & \text { TN } & \text { TN } & M, \text { St } & M+\end{array}$

CVYV-SU96-84 M, VB, St TN 0 (nec) mo $\quad M+(n e c)$

$\begin{array}{lllll}\text { CVYV-SU12-10 } & M & 0 & \text { nec } & \text { mo }\end{array}$

CVYV-TN05-56 M TN nec mo M (nec)

$\begin{array}{llllll}\text { CVYV-OM04-06 M, VB } & \text { TN } & M & M+(n e c)\end{array}$

\begin{tabular}{cccccc} 
CVYV-LIB & $M$ & $T N$ & $T N$ & mo & $M+$, VB \\
\hline CVYV-PI1 & $M-$ & $M+$ & $T N$ & mo & $M+$
\end{tabular}

$\begin{array}{llllll}\text { CVYV } 3.1 \text { (clone) } & M & 0 & \text { TN } & \text { mo } & \text { M+ }\end{array}$

$\begin{array}{lllllll}\text { CVYV-VPg-C1 } & \text { mo } & \mathrm{M}+ & \mathrm{TN} & \text { mo } & \mathrm{M}+\end{array}$




\section{Figure legends}

525 Figure 1: Symptoms induced by CVYV-Esp on different melon accessions (a) mosaic on Védrantais;

526 (b) severe mosaic on Ouzbeque 2; (c) lethal necrosis on HSD 93-20-A; (d) very mild mottle on HSD

527 2458, (e) lack of infection on PI 164323; (f) occasional necrosis on PI 164323.

528 Figure 2a: Alignment of VPg amino acid sequences of twelve CVYV isolates and eight other 529 ipomoviruses. The "K" mutation present in CVYV-PI1 is indicated in bold.

530 Figure 2b : Overlay of predictions of disorder for the VPg of CVYV-Esp (in red) and CVYV-PI1 (in 531 dark blue).

532 Regions of the VPg with a predicted PONDR score above 0.5 are considered as disordered. The 533 thick black line indicates a propensity of the region to fold in a secondary structure, maybe in 534 contact with an interactor. The arrow indicates the position of the $E_{90} \mathrm{~K}$ mutation.

\section{Supplementary material}

537 Supplementary table S1: Primers used to obtain the infectious clone of CVYV

539 Supplementary figure S2: PONDR prediction of disorder for the VPg of CVYV-Esp, three 540 ipomoviruses -squash vein yellowing virus (SqVYV), cassava brown streak virus (CBSV) and Uganda 541 cassava brown streak virus (UCBSV)- and four potyviruses potato virus Y (PVY), zucchini yellow 542 mosaic virus (ZYMV), papaya ringspot virus (PRSV) and turnip mosaic virus (TuMV). Regions of the 543 VPg with a predicted PONDR score above 0.5 are considered as disordered. The thick black line 544 indicates a propensity of the region to fold in a secondary structure, maybe in contact with an 545 interactor. 

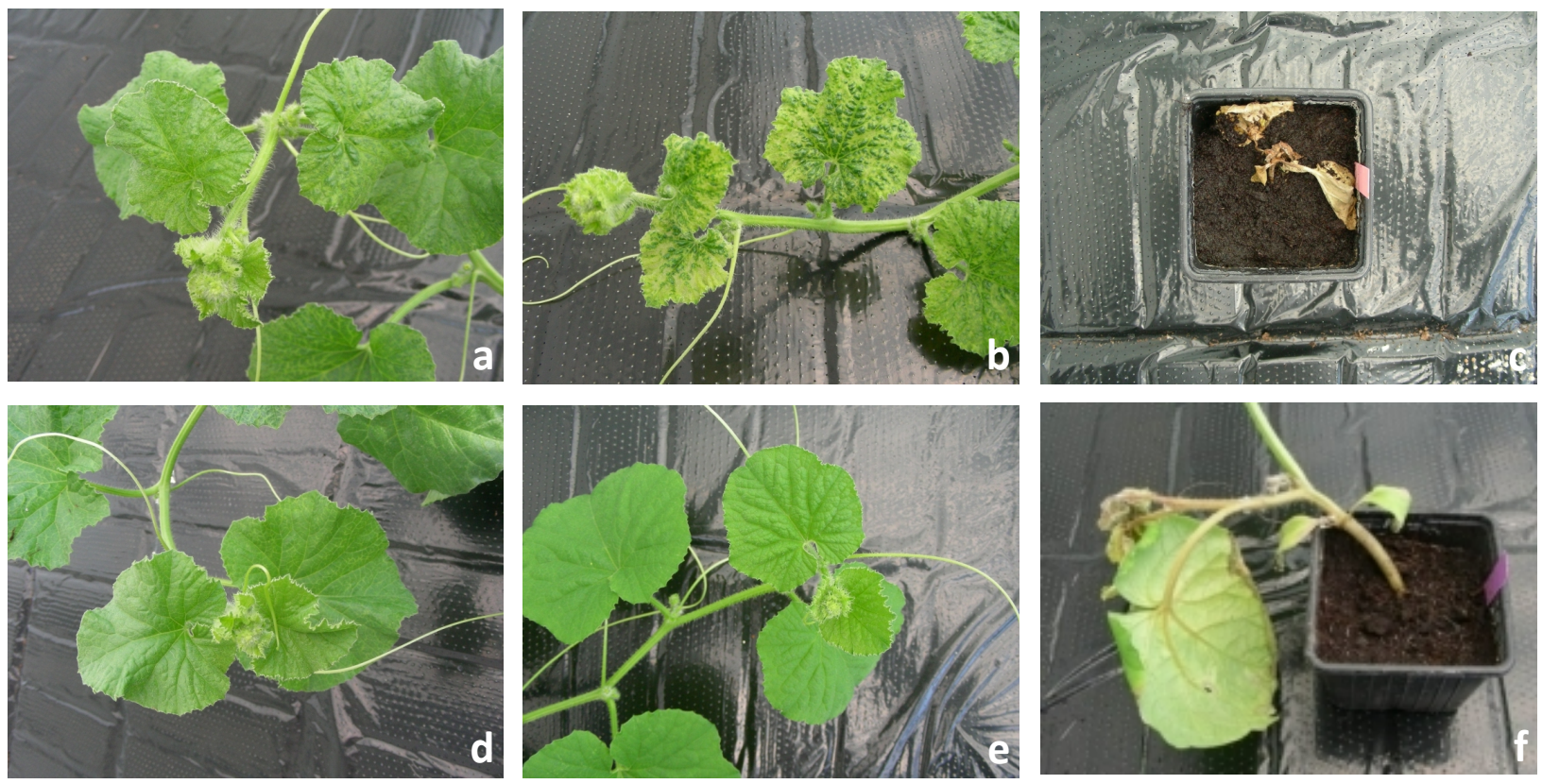

Figure 1 
CVYV-Esp CVYV-PII TN05-56 LIB

ALM32

SU96-84 SU12-10 JOR

IR02-106

ISR

ISM

OM0 4-0 6

CocMoV

SqVYV-FL

SqVYV-cHe

SqVYV-IL

SqVYV-Ir

CBSV

UCBSV

SPMMV

---GKVGYRR DKRVGRFVFD GPDEDIIENF GVEYSHDVVT KKMSKAQKLK QAKEKGWKIG KVDRPKKIFR QLYGVNPLEF DEVYLTVGDF KGEVWETKD-

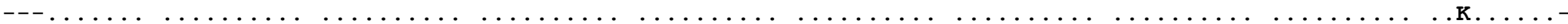
.

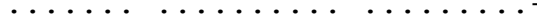

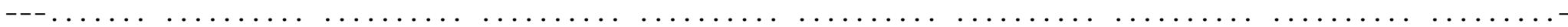
-

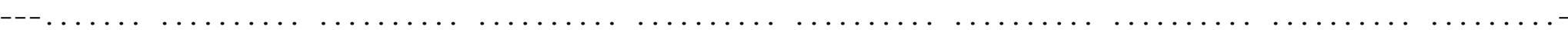

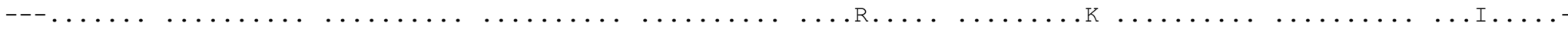

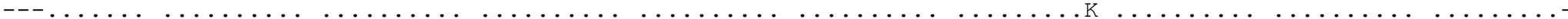

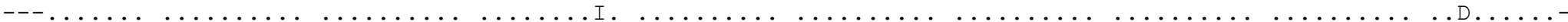

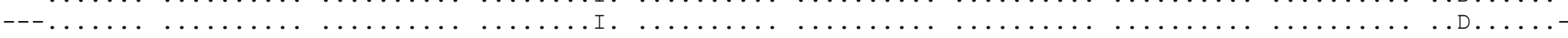

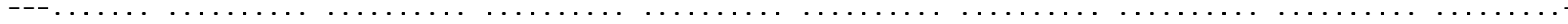

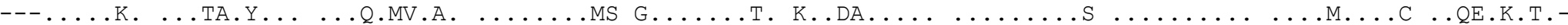

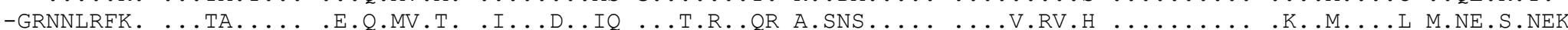

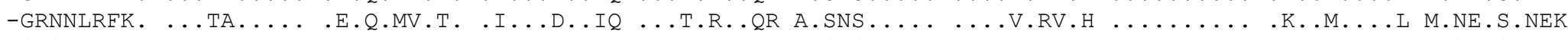

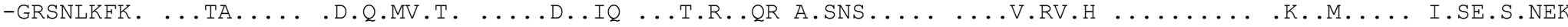

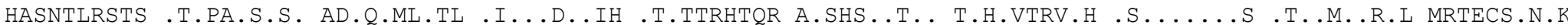

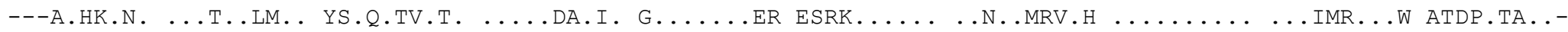

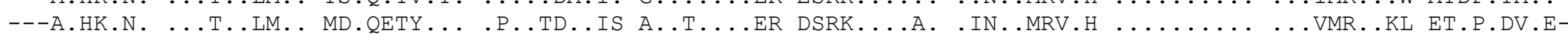
HG-K.IRLN. ...NAC ...S .T.DAMV.EY ......IH GR ....AR .M.L..K.P. SDT.-V.P.K V...ID.NDY .T.A.SA.GL TT.AVPVGE-

MDIDEMYSDL YSDFNLGNR- KGYSKDVYLV FSKKDSDIEA VIDLQPHRSK MASSMSLNPM GFPEEEGRWR QSGDVKMRKR IEEE------ -VEVQ

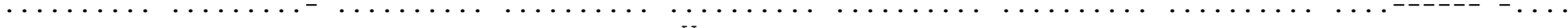

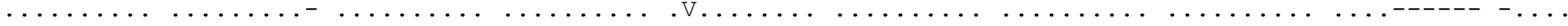

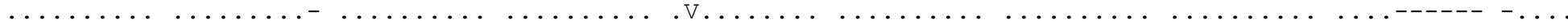

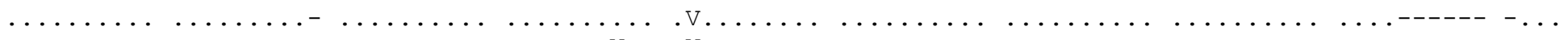

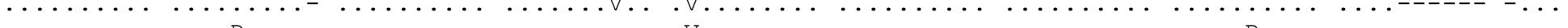

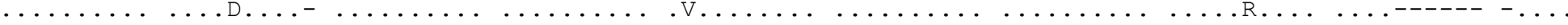

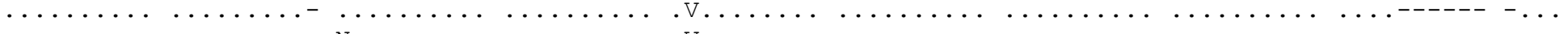

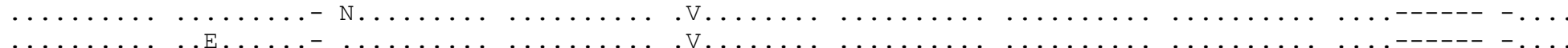

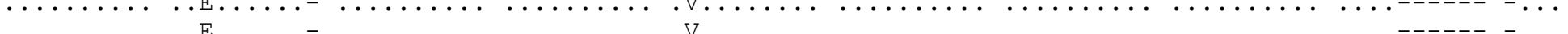

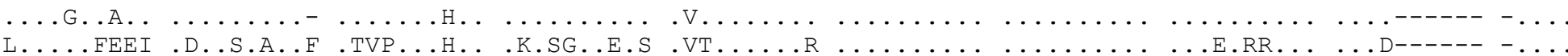

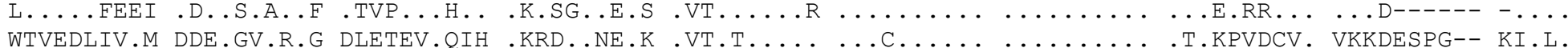
WTVEDLIV.M DDE.GV.R.G DLETEV.QIH .KRD..NE.K.VT.T...................K.KPVCV. .KKDESPG-- KI.L. WTVEDLIV.M DDE.GV.R.G DLETEVIQIH .KRDN.NE.K.VT.T..K.................OPVDCV.V.K.KSSG-- OI.L. WTVEDLIV.M HD.SGV.R.G DLDTEL.HIH SKRD..NEDK .VT.T...T ... . .......D.R....T.KPVD.V. VKKDESPA-- TL.LH

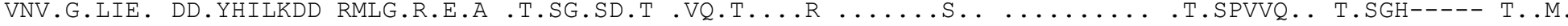
LNV.A.MIE. DD.YHILRDD RMFG.K.S.A.R.EGA.E.T IVN.T.....T.............T.APLI-.K T.K.D----- E... ASLIDLMLE. DDETGIFR-- .QVVNELK.K YTNNANGEQ. MVR.T..D.R R.TIG.FM.S ..DHH.E.. .T.AAEII.N VAVDSHVGTP T.DAE

\section{Figure $2 a$}




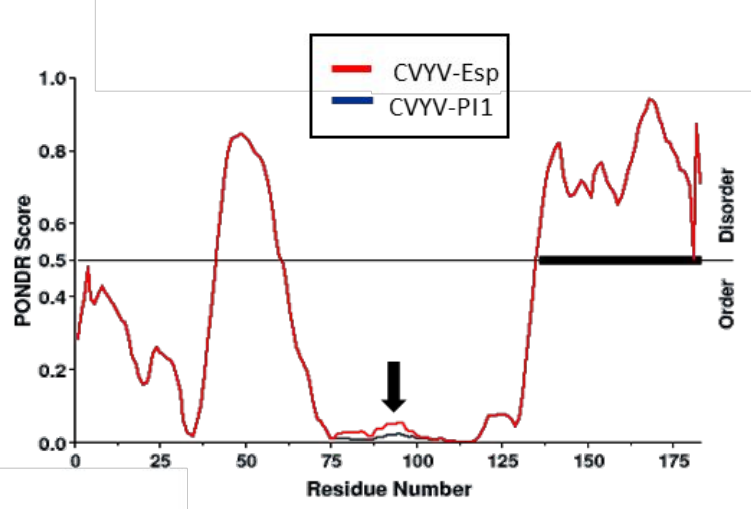

Figure $2 b$ 


\begin{tabular}{lll}
\hline Name & Position & Sequence \\
\hline CVYV-1F & $1-25$ & $\begin{array}{l}\text { ATATAAGGAAGTTCATTTCATTTGGAGAGGAAAATAAACATTACATGAAA } \\
\text { TTACA }\end{array}$ \\
CVYV-1R & $2823-2847$ & CTCTACATCTTCTAACAAACTTAA \\
CV-P3-intron1-F & $2823-2847$ & TTAAGTTTGTAGAAGATGTAGAGGTAAGTTTCTGCTTCTACC \\
CV-P3-intron1-R & $2848-2870$ & TGTGAAAACTCAATGCACGCATCCTGCATATCAACAAATTTTG \\
CVYV-2F & $2848-2870$ & GATGCGTGCATTGAGTTTTCACA \\
CVYV-2R & $4023-4048$ & CTGTTCTAACTCTCCCTCTGTACGC \\
CV-Cl-intron2-F & $4023-4048$ & GCGTACAGAGGGAGAGTTAGAACAGGTAAGTATGCACTTAAAGA \\
CV-Cl-Intron2-R & $4049-4068$ & AACCGTGATGGGTTGCGTTCCTGCATAATTTCAAAGATTG \\
CVYV-3F & $4049-4073$ & AATTATGCAGGAACGCAACCCATCACGGTTATGAC \\
CVYV-3R & $5746-5765$ & ATRATGTCCACATCAGGTCC \\
CVYV-4F & $5356-5375$ & TTGATGGTTGGTTGGATACC \\
CVYV-4R & $7309-7328$ & TAGAGAGCTCCCATTGCGGC \\
CVYV-5F & $7105-7124$ & TATGGYCCAAGTGTGATGAC \\
CVYV-5R & $9733-9751$ & GCGAATCTAGATTTTTTTTTTTTTTTTTTTATAACTTTACGCATAAAGG \\
\hline
\end{tabular}

Supplementary table S1. Primers used for PCR amplification of CVYV-Esp in order to obtain the fulllength infectious clone containing two introns.

Underlined sequences correspond to the extremities of the introns. Sequences in italics correspond to the extremities of the vector 
Page 30 of 30

CVYV

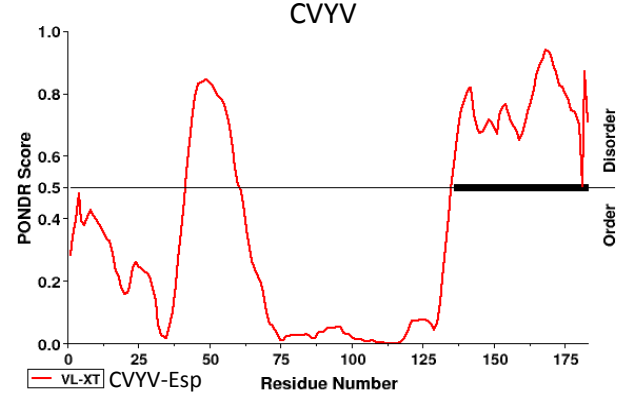

SqVYV
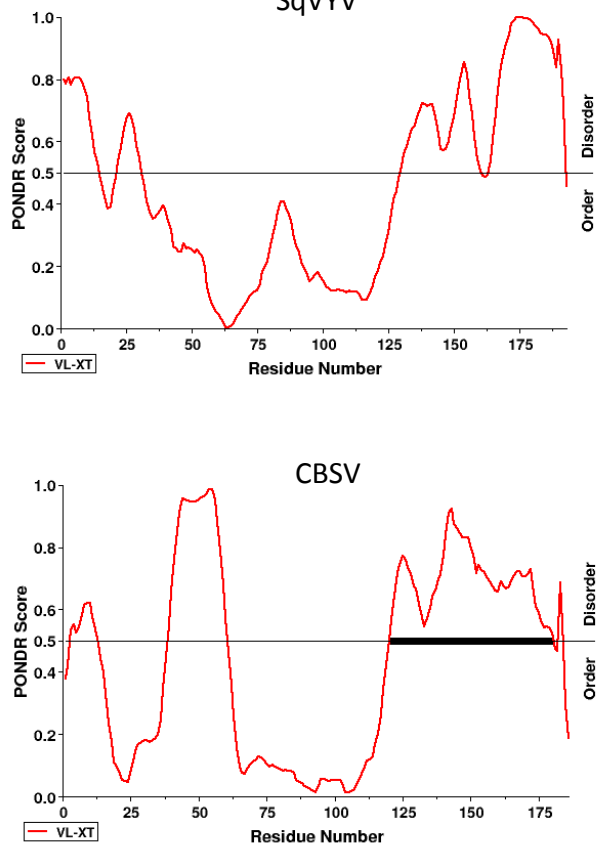

UCBSV

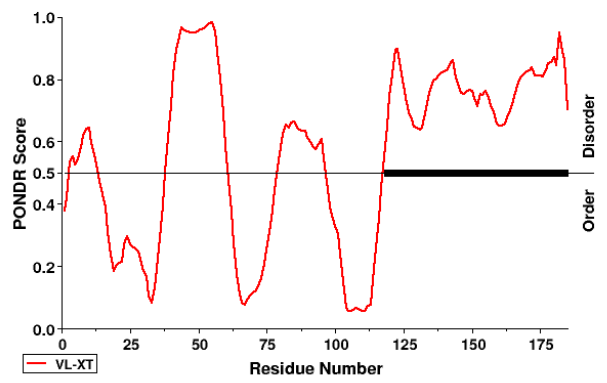

PVY

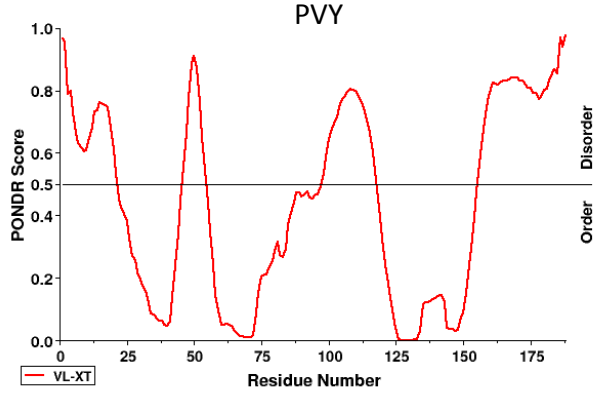

ZYMV
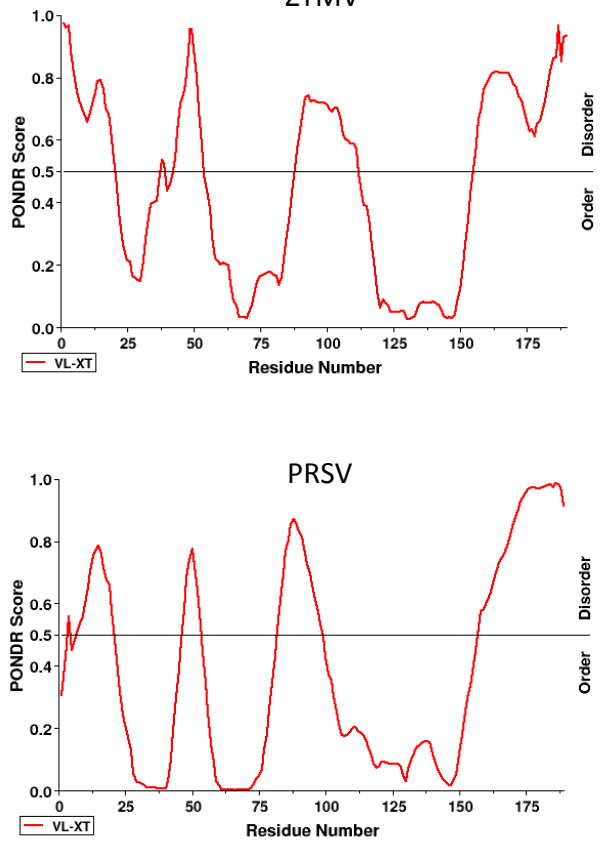

TuMV

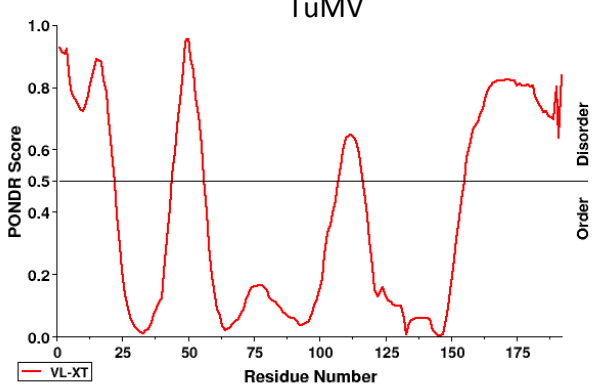

Supplementary figure S2 